\title{
Deep-water agglutinated foraminifera from the Lower Cretaceous (Neocomian) 'Complex à Aptychus' Formation (Corridor de Boyar, Betic Cordillera, southern Spain)
}

\author{
WOLFGANG KUHNT \\ Geologisch-Paläontologisches Institut und Museum der Universität, Olshausenstr. 40, D-24118 Kiel, Germany.
}

\begin{abstract}
The oldest deep-water sediments of the flysch units in the western part of the Betic Cordillera (southern Spain) are red and green pelagic claystones with intcrcalated siliciclastic and carbonate turbidites, ranging from Berriasian to Barremian in age. Autochthonous and redeposited benthic foraminiferal assemblages were studied in outcrops of this 'Complex à Aptychus' Formation in the 'Corridor de Boyar' near Grazalema. The assemblage of the autochthonous red and green claystones is wholly comprised of agglutinated forms, reflecting deposition beneath the calcium carbonate compensation depth (CCD). Compared to coeval abyssal and deep bathyal assemblages from the NW Australian Margin (Eastern Tethys), the Polish Outer Carpathians and the North Atlantic, the assemblage from the Betic Flysch Zone is more related to its Tethyan equivalents and may represent a truly abyssal Early Cretaceous sub-CCD environment. J. Micropalaeontol. 14(1): 37-52, April 1995.
\end{abstract}

\section{INTRODUCTION}

Lower Cretaceous litho- and biofacies which are typical of a sub-calcium carbonate compensation depth (CCD) environment are poorly represented in the North Atlantic and western Mediterranean orogenic belt due to a relatively deep CCD in the Western Tethys at the time (deeper than $4 \mathrm{~km}$ according to Tucholke \& Vogt, 1979). Typical Lower Cretaceous sedimentary formations in this area are the Blake Bahama Formation (Jansa et al., 1979) in the North Atlantic and the rather similar Majolica Formation in the Western Mediterranean area, both ranging from late Tithonian to Barremian in age. Pelagic limestone deposition prevailed throughout this time interval. Oxygenated seafloor-conditions persisted throughout the Berriasian, but beginning in the Valanginian there is evidence for increasingly common episodes of poorly oxygenated bottom water (Tucholke \& Vogt, 1979). Owing to the dominance of pelagic limestones in deep-water sequences and the often poorly oxygenated conditions in intercalated shaly intervals occurrences of rich benthic deep-water forminiferal assemblages from this time interval are exceptional curiosities. Lower Cretaceous abyssal and deep bathyal foraminiferal assemblages have so far been described from the Argo Abyssal Plain off the NW Australian Margin in the Eastern Tethys (Kuznetsova, 1974; Bartenstein, 1974; Riegraf \& Luterbacher, 1989; Kaminski et al., 1992), the Cieszyn Limestone Formation in the Polish Outer Carpathians (Geroch \& Olszewska, 1990), and the Blake-Bahama Fomation of the North Atlantic (Luterbacher, 1972; Maync, 1973; Kuznetsova \& Seibold, 1977; Gradstein, 1978; Sigal, 1979; Sliter, 1980; Riegraf \& Luterbacher, 1989).

During a re-examination of the oldest deep water sediments of the flysch units in the western termination of the Betic Chain and the Campo de Gibraltar, the so-called 'Complex à aptychus' Formation (Didon et al., 1973), the so far oldest well-preserved and diverse abyssal agglutinated foraminiferal assemblage of the Western Mediterranean was found in the Corridor de Boyar Unit near Grazalema. Eleven large bulk samples of $1-2 \mathrm{~kg}$ weight were removed from various lithologies in the "Complex à aptychus" formation in the Corridor de Boyar (western part of the Betic Cordillera, Andalousia). Six of these samples, which were removed from greyish marlstones and greenish claystones were completely barren or contained only non identifiable fine-grained carbonate detritus, indicating that these sediments represent fine-grained parts of turbidites. Four samples from coarse grained laminated and graded turbidity sequences are mainly made up by fragments of aptychii and contain rich redeposited assemblages of benthic foraminifera. This study mainly focuses on autochthonous abyssal agglutinated foraminifera from two large bulk samples of the multicolored claystone in the lower part of the 'Complex à aptychus' formation. The bulk samples have been split in several subsamples, completely desintegrated in diluted buffered hydrogen peroxide and anionic tensides and washed over a $63 \mu \mathrm{m}$ sieve. Four replicate samples were completely picked for foraminifera. The assemblages of 400-800 specimens were mounted in Plummer-slides, determined and counted.

The two main objectives of this taxonomic and palaeoenvironmental analysis of the autochthonous agglutinated foraminifera of the 'Complex à aptychus' Formation in the Corridor de Boyar are:

(1) using benthic foraminiferal assemblages as a tool for the reconstruction of the Early Cretaceous palaeoenvironment and palaeobathymetric evolution of the Alboran Margin;

(2) achieving a better understanding of the palaeogeographic position of the Corridor de Boyar deep-water basin by comparison of its benthic foraminiferal assemblages with coeval abyssal and deep bathyal assemblages from Argo Abyssal Plain (NW Australian Margin, Eastern Tethys), the Cieszyn Limestone Formation in the Polish Outer 
Carpathians, and the Blake-Bahama Fomation of the North Atlantic, and thereby evaluating the potential of Lower Cretaceous deep water agglutinated foraminiferal (DWAF) assemblages for studies of Tethyan palaeobiogeography and palaeoceanography.

\section{SAMPLE LOCALITY}

Objective of this study is to examine the age and palaeoenvironment of the stratigraphically oldest formation within the 'Corridor de Boyar' Unit near Grazalema. This unit is situated in the western part of the Betic Cordillera,

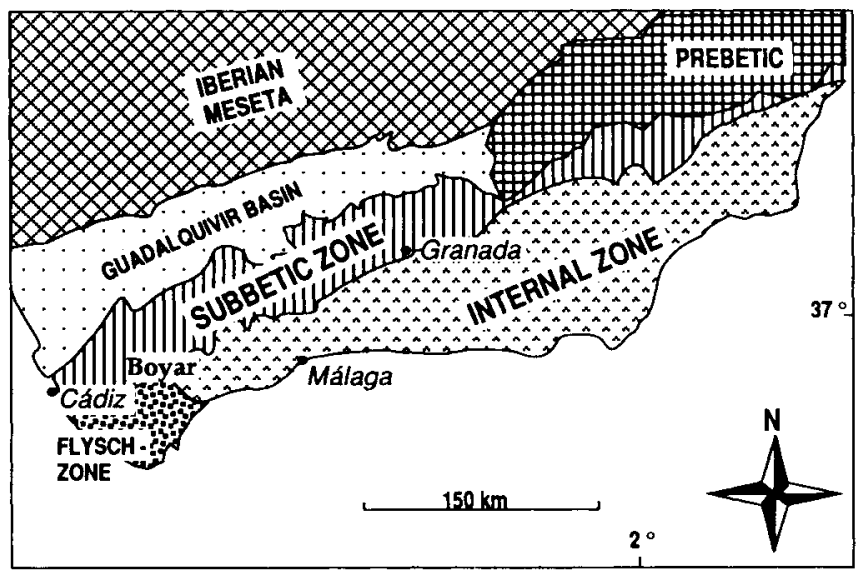

Fig. 1. Main structural units of the Betic Cordillera (southern Spain). Compiled using data of Azema et al. (1979) and IGME. Geological Map 1:400 000. where autochthonous pelagic sediments of the 'Betic Seaway' (Subbetic Zone, Fig. 1.) interfinger with the flysch units of the Campo de Gibraltar (Fig. 1). Occurrences of this Berriasian-Barremian 'Complex à aptychus' formation are scarce in this area and generally covered by vegetation. However, outcrops in the surroundings of a small mountain pass, about $1 \mathrm{~km}$ NNW of the village of Grazalema $(4071.800 \mathrm{~N}, 288.300 \mathrm{E}$, sheet 14-44 Ubrique of the Mapa Militar de España 1:50 000) allow not only sampling of the turbiditic beds but also the intercalated hemipelagic and pelagic multicolored claystones (position of the locality is indicated as 'Boyar' on Figs 1 and 2).

\section{GEOLOGICAL SETTING}

The structural and palaeogeographical setting of the 'Corridor de Boyar' near the village of Grazalema has been a point of vigorous discussion since the classic works of Blumenthal $(1927,1935 a, 1935 b, 1936)$ and Fallot $(1930$, 1948). At the Puerto de Boyar, west of Grazalema a Lower Cretaceous flysch type sedimentary sequence is tectonically sandwiched between a Penibetic carbonate platform sequence to the south and an Upper Jurassic carbonate platform sequence to the North (Sierra del Pinar). The origin and palaeogeographical position of this northern unit has been interpreted in very different ways. Hoeppener et al. $(1964 a, b)$ preferred a reconstruction where the present arrangement of units corresponds to their former palaeogeographical position. Hoppe (1968) regarded the Sierra del Pinar as part of a large overthrusted mass, the root of which may have been south of the Penibetic, but regarded the flysch-type sediments of the Corridor de Boyar as

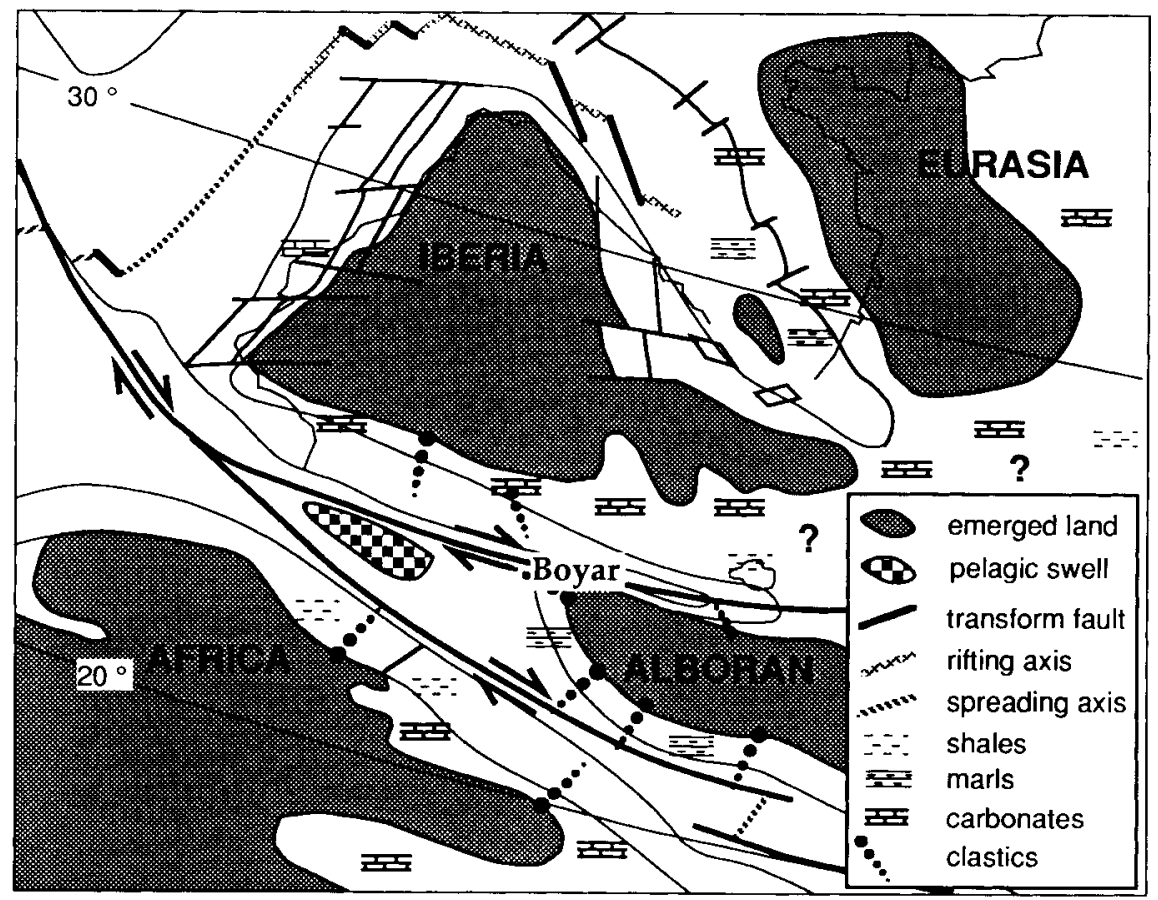

Fig. 2. Palaeogeographical reconstruction of the western Mediterranean realm for the Lower Cretaceous (Anomaly M0, Lower Aptian). The reconstruction is based mainly on the $110 \mathrm{Ma}$ (Aptian) Tethyan palaeogeographical map of Dercourt $e t$ al. (1985). It is supplemented by new observations in the surroundings of the Alboran microplate (Reicherter, Pletsch \& Kuhnt, pers. comm.). Note the original position of the Corridor de Boyar basin lateral to the Penibetic pelagic swell. 
autochthonous. More recent reconstructions (Dubois, 1971; Bourgois, 1978) suggested also for the Corridor de Boyar sequences a palaeogeographical origin south of the Penibetic and considered the Sierra de Pinar units as part of the stratigraphic basement of the Corridor de Boyar sequence. Thurow (1987) suggested a close palaeogeographical relationship between the Median Subbetic units and the Corridor de Boyar sequences from similarities in the composition of their clastic components. Consequently the palaeogeographical position of these units is regarded as north of the Penibetic zone. In all these reconstructions surprisingly little attention has been paid to the possible influence of lateral movements on the present-day configuration of structural units. Leblanc \& Olivier (1984) estimated a $400 \mathrm{~km}$ dextral lateral displacement of the Alboran block along its northern margin (the North Betic Fault). Important lateral displacements may also have affected the more northerly palaeogeographical zones and it is quite possible, that the present day $\mathrm{N}-\mathrm{S}$ transect across the Corridor de Boyar includes units that were originally situated several hundred kilometres to the east.

The theory of Bourgois (1978), that the sedimentation within the Corridor de Boyar is the stratigraphic continuation of the Sierra del Pinar sequence is now widely accepted (Durand Delga, 1980; Thurow, 1987). The Sierra del Pinar is formed by a thick Liassic carbonate platform, which was drowned during the late Dogger and early Malm (Bathonian?-Kimmeridgian), approximately coeval with the formation of the Mauretanian basin, the Betic seaway and the deep central North Atlantic. Durand Delga (1980) compared the palaeogeographical position of the Corridor de Boyar series with the Djebel Moussa in Northern Morocco, which can be regarded as a deep part of the Alboran Margin (Predorsalien Unit in the sense of Olivier, 1984). Its strange present day position north of the Penibetic Unit can be explained by a northward transport of the unit by large-scale overthrusting or within gigantic olisthostromes (Bourgois, 1978) or, more likely, by dextral strike-slip and/or rotational movements parallel to the major dextral strike-slip zone which separates the internal and external Betic Zones (Durand Delga, 1980). In both cases, the Sierra del Pinar-Corridor de Boyar sedimentary sequence can be regarded as part of the late Jurassic-Cretaceous continental margin of the Alboran microcontinent (Fig. 2).

\section{THE 'COMPLEX À APTYCHUS' NORTH OF GRAZALEMA}

The sedimentary succession within the Corridor de Boyar Unit was intially described by Bourgois (1978). A recent re-examination of the sequence (Thurow, 1987) added more detailed sedimentologic descriptions and a precision of the biostratigraphy using radiolarian assemblages but did not substantially change the initial stratigraphic subdivisions (Fig. 3). This study concentrates on the stratigraphically deepest units (subunits A1-A3 according to Bourgois, 1978), which can be observed NNW of Grazalema in a tectonically disturbed but generally continuous succession from $\mathrm{W}-\mathrm{E}$. The oldest subunit (A1) is the only sequence where autochthonous deep-water foraminiferal assemblages have been obtained. A typical sedimentary sequence within this subunit comprises fine-grained carbonate turbidites with a maximum thickness of $20-30 \mathrm{~cm}$, and hemipelagic and pelagic claystones with a thickness of a few tens of centimetres (Fig. 3). The whole sequence is intensely tectonically folded, and synsedimentary folding can also not be excluded. The overlying unit (A2) contains siliciclastic turbidites of up to $50 \mathrm{~cm}$ in thickness and intercalated calcareous-marly sediments ('preflysch' of the French authors). Micropalaeontologic samples from the marly hemipelagic layers in this unit were barren, but samples from the bases of turbidites yielded rich redeposited assemblages of typical Tethyan outer shelf and slope benthic foraminifers of Berriasian to Barremian age. The following age-diagnostic species have been identified:

Lenticulina eichenbergi Bartenstein \& Brand, 1951

Dorothia praehauteriviana Dieni \& Massari, 1966

Occasionally redeposited macro-invertebrates have been found, which allow a tentative dating of this subunit as Berriasian to Valanginian. Characteristic forms are (Bourgois, 1978 and sample E30/20):

Lamellaptychus gr. beyrichi (Oppel)

Lamellaptychus cf. aplanatus (Gill)

Lamellaptychus gr. seranonis (Coquand)

Lamellaptychus cf. mortilleti (Pictet \& Loriol)

Lamellaptychus submortilleti Trauth

Punctaptychus ex gr. punctatus (Voltz).

\section{FAUNAL CHARACTERISTICS} AND PALAEOENVIRONMENT

Autochthonous benthic foraminiferal assemblages are exclusively made up of agglutinated foraminifera with organic, diagenetically silicified cement. Calcareous benthic foraminifera and agglutinated foraminifera with carbonate cement occur only in redeposited assemblages.

A striking characteristic of the Early Cretaceous abyssal agglutinated foraminiferal assemblage is a small test size. Tests with a maximum length of more than $200 \mu \mathrm{m}$ make up less than $1 \%$ of the total assemblage and forms larger than about $400 \mu \mathrm{m}$ are virtually absent. This unusual size distribution can be either explained by slow growth rates due to limited resources, or by high reproduction rates which may have been triggered by short seasonal spikes in phytodetritus supply, as it can be observed in Recent oligotrophic deep-sea areas.

Tubular morphotypes with epifaunal habitat (e.g. Rhizammina indivisa) are generally rare. However, the fossilization potential of these forms is low and is probably dependent on sedimentation rates. Since sedimentation rates in the early Cretaceous of the Corridor de Boyar were undoubtedly low, a lack of epifaunal soft-walled agglutinated foraminifera such as rhizamminids is not surprising.

Significant differences are observed between assemblages from red claystones (referred here as type A assemblages), indicating oxic bottom water conditions and from green claystones (type B assemblages, mildly dysaerobic bottom waters, see Fig. 3). Infaunal morphotypes such as 

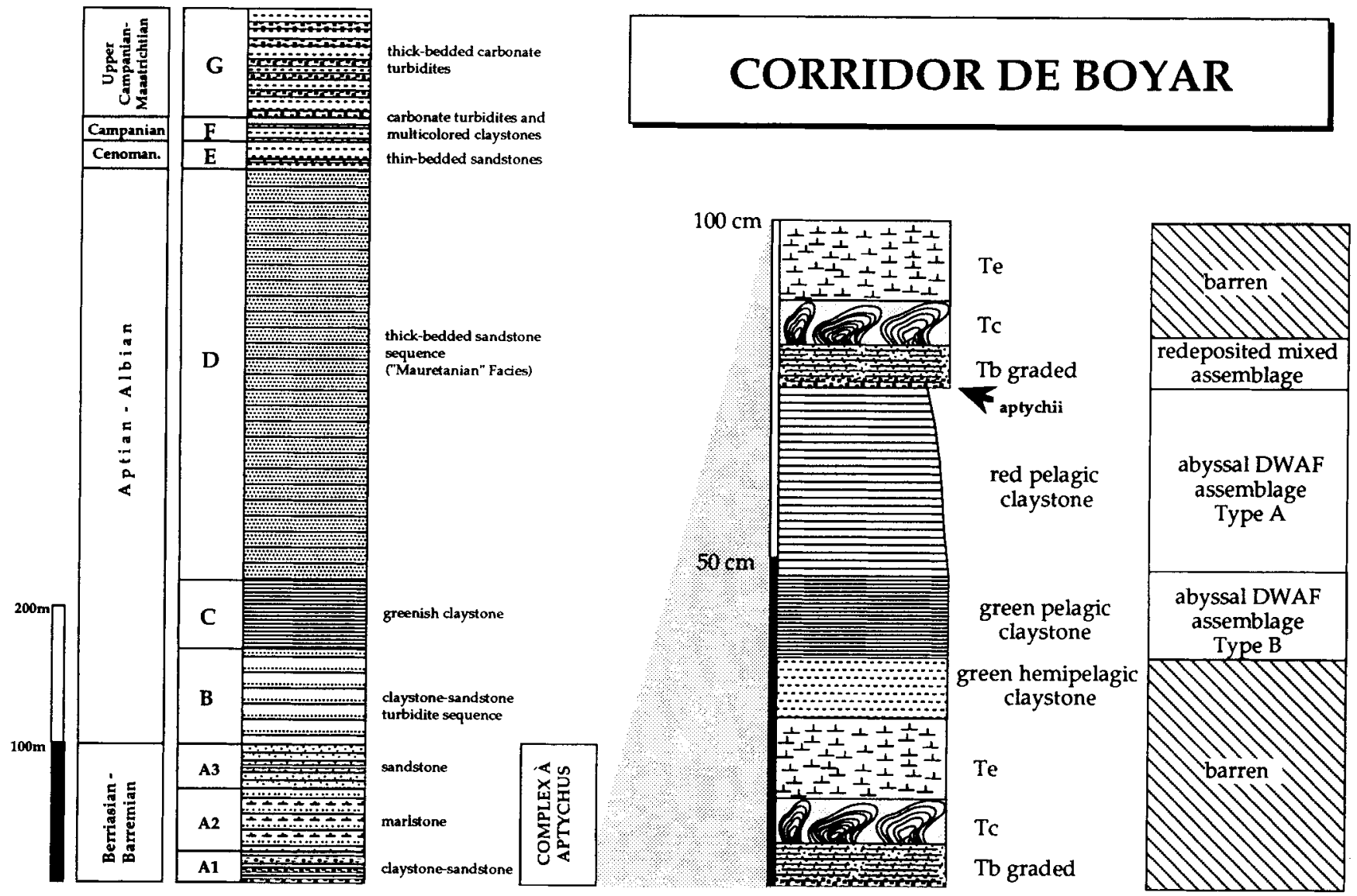

Fig. 3. Synthetic stratigraphic column of the Corridor de Boyar flysch (modified from Bourgois, 1978) and typical sequence within the Subunit A1 of the 'Complex à aptychus' Formation. In the studied outcrop these sequences are now generally overturned and intensely folded. No autochthonous benthic foraminiferal assemblages are so far known from the units D to F in the Corridor de Boyar area. These sequences may consist exclusively of redeposited material.

Verneuilinoides, Pseudobolivina, Pseudoreophax and Bulbobaculites dominate in the red claystones (Table 1, Fig. 4). These four genera make up about $60 \%$ of the assemblage. Ammodiscids are mainly represented by the species Glomospira gordialis and Glomospira charoides, which occur as infauna in Recent deep sea sediments (Gooday, 1990; Kuhnt, Collins \& Scott, unpublished observations). Planispiral ammodiscids also occur, but there is an unusual dominance of the genus Glomospirella, whereas true Ammodiscus have only been observed in single specimens. All these aspects of the 'red' assemblages point to a deep-water environment, which is largely sheltered from terrigeneous detritic flux, oxic (cool?) bottom water masses, generally low surface productivity, and possibly a pronounced seasonality in phytodetritus supply from primary production.

Assemblages from green claystones differ from the 'red' assemblages mainly in the distribution pattern of the genera Pseudoreophax, Bulbobaculites, Haplophragmoides, Glomospirella and Glomospira (Fig. 4). Pseudoreophax and Bulbobaculites are almost absent in the 'green' assemblage. Both these forms can be regarded as infaunal morphotypes which may be sensitive to a Redox-line close to the sediment surface. A similar occurrence restricted to red, oxic claystones has been observed for the Cenomanian-Turonian species Bulbobaculites problematicus in the Carpathians and the North Atlantic (Kuhnt \& Kaminski, 1990). The genera Haplophragmoides, Glomospira and Glomospirella are significantly more abundant in 'green' assemblages (Fig. 4). These forms are characteristic representatives of Biofacies B assemblages (Kuhnt et al., 1989), which characterize environments under mildly oxygen-deficient conditions at the sea-floor and probably increased surface water productivity. Their life habitat has been interpreted as epifaunal detritus-feeders which can take advantage of enhanced food supply from phytodetritus and are less sensitive to oxygen deficiency.

\section{PALA EOBIOGEOGRAPHICAL ASPECTS}

The new observations on earliest Cretaceous deep-water agglutinated foraminifera in the Corridor de Boyar of the Betic Cordillera confirm the cosmopolitan distribution of these forms. Most of the 18 genera and 26 species observed in the Berriasian-Valanginian of the 'Complex à aptychus' 


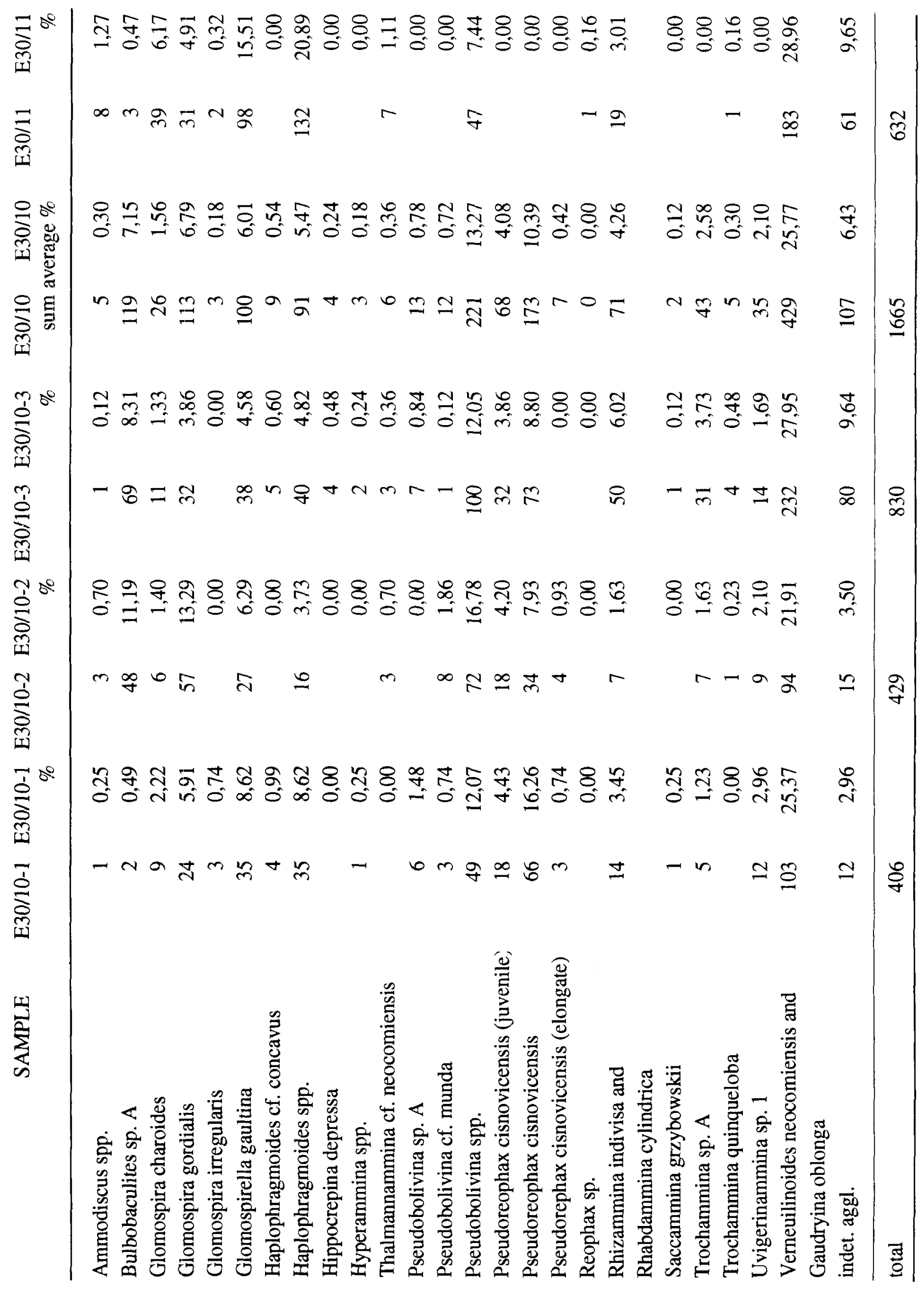


RED CLAYSTONE

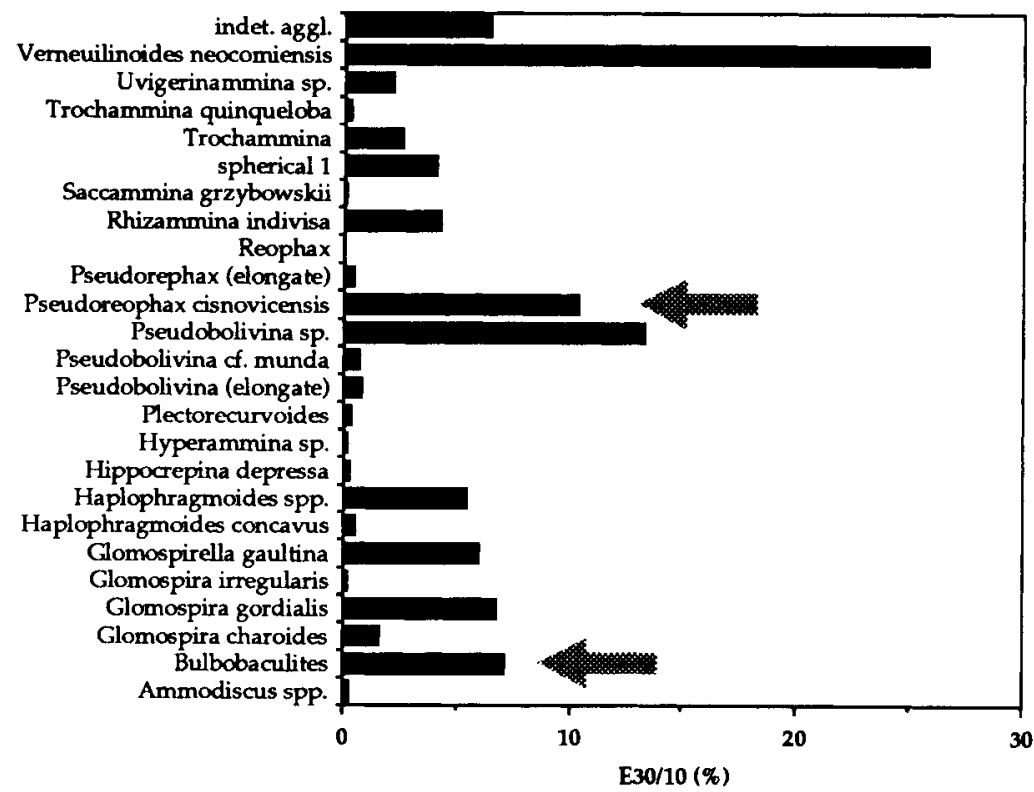

GREEN CLAYSTONE

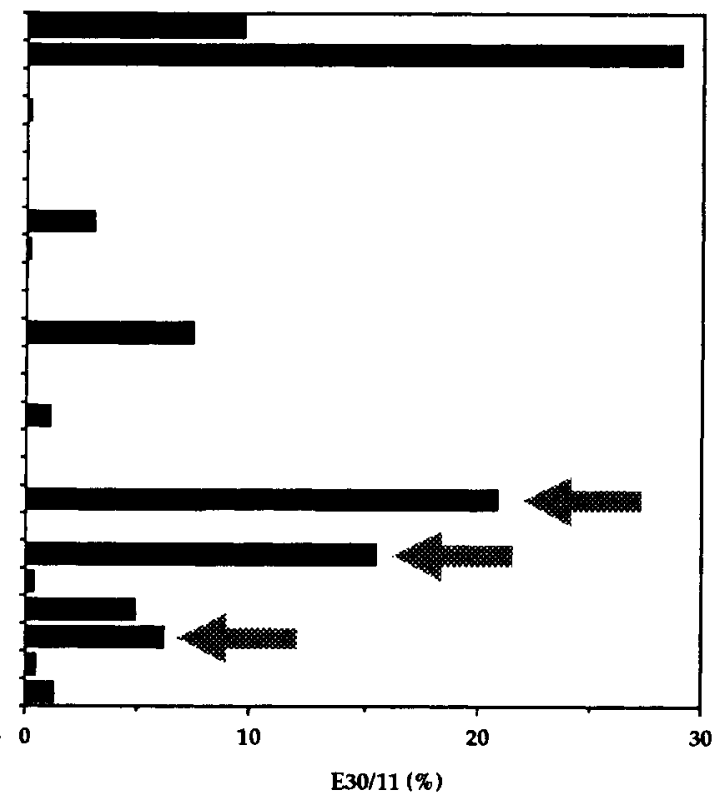

Fig. 4. Quantitative composition of autochthonous deep-water agglutinated foraminiferal assemblages from green and red claystones in the 'Complex à aptychus' unit. The plot is based on 1665 specimens counted from red claystones and 632 specimens counted from green claystones. Arrows indicate forms with significant differences in distribution between red and green claystones.

unit seem to occur within the entire Tethys ocean. Occurrences of similar assemblages are known from the West Australian Margin (Indian Ocean $=$ Eastern Tethys), the Polish Carpathians and the Central North Atlantic (= western termination of the Tethys ocean). However, this type of 'Tethyan' abyssal and deep-bathyal assemblages is not known from high latitude areas. It may be speculated that most of the forms observed in these assemblages have their ecological niche in deep-sea environments with restricted resources, and are unable to compete with other forms in more favourable environments.

\section{CONCLUSIONS}

The Cretaceous turbiditic sequences of the Corridor de Boyar unit were deposited in a deep continental margin setting close to the western termination of the Alboran Block. Sediments and autochthonous benthic foraminiferal assemblages within the Corridor de Boyar basin represent a truly abyssal sub-CCD environment as early as in Berriasian-Valanginian times. The foraminiferal assemblage is composed of cosmopolitan forms, fairly diverse (26 species) and not dominated by single species. Red sediment colour and the presence of numerous infaunal benthic foraminiferal morphotypes indicate well-oxygenated bottom-water conditions within the basin. From these observations can be concluded that during BerriasianValanginian times the Corridor de Boyar flysch basin was connected to the belt of Lower Cretaceous flysch basins within the western Tethys (Durand Delga, 1980) and had deep-water connections to the Tethys ocean and the central North Atlantic abyssal basin. The main subsidence phase of this part of the western Alboran margin was already terminated in the Berriasian-Valanginian and probably took place within a short time interval in the latest Jurassic. This Late Jurassic subsidence phase coincides with the first formation of oceanic crust on the Tagus Abyssal Plain (Mauffet et al., 1989). Transform directions associated with this old spreading ridge are WSW-ENE (Malod, 1989) and thus in agreement with the general trend of the northern margin of the Alboran block at this time (compare Fig. 2). Kinematic reconstructions of the Iberian plate (Malod, 1989) predict a significant extension between Africa and Iberia during the Late Jurassic rifting. It may be speculated that the abyssal Corridor de Boyar basin was formed along a transform-margin of the Alboran block during a Late Jurassic extensional phase, which affected not only the

\section{Explanation of Plate 1}

Fig. 1. Rhizammina indivisa Brady (1884), sample E30/10, $\times 170$. Fig. 2. Rhabdammina cylindrica Glaessner 1937, sample E30/10, $\times 170$. Fig. 3. Hyperammina gaultina Ten Dam 1950, sample E30/10, $\times 170$. Fig. 4. Hyperammina cf. dilatata Grzybowski 1896, sample E30/10, $\times 170$. Fig. 5. Hippocrepina depressa Vasicek 1947, sample E30/10, $\times 170$. Figs 6-7. Ammodiscus tenuissimus (Guembel 1862), sample E30/11, 6: $\times 170,7$ : $\times 240$. Figs 8-9. Glomospira charoides (Jones \& Parker 1860), sample E30/10, $\times 240$. Fig. 10. Glomospira gordialis (Jones \& Parker 1860), sample E30/10, $\times 200$. Fig. 11. Glomospirella gaultina (Berthelin 1880), sample E30/10, $\times 125$. Figs 12-13. Glomospira irregularis (Grzybowski 1898), sample E30/10, $\times 170$. Fig. 14. Saccammina grzybowskii (Schubert 1902), sample E30/10, $\times 170$. 


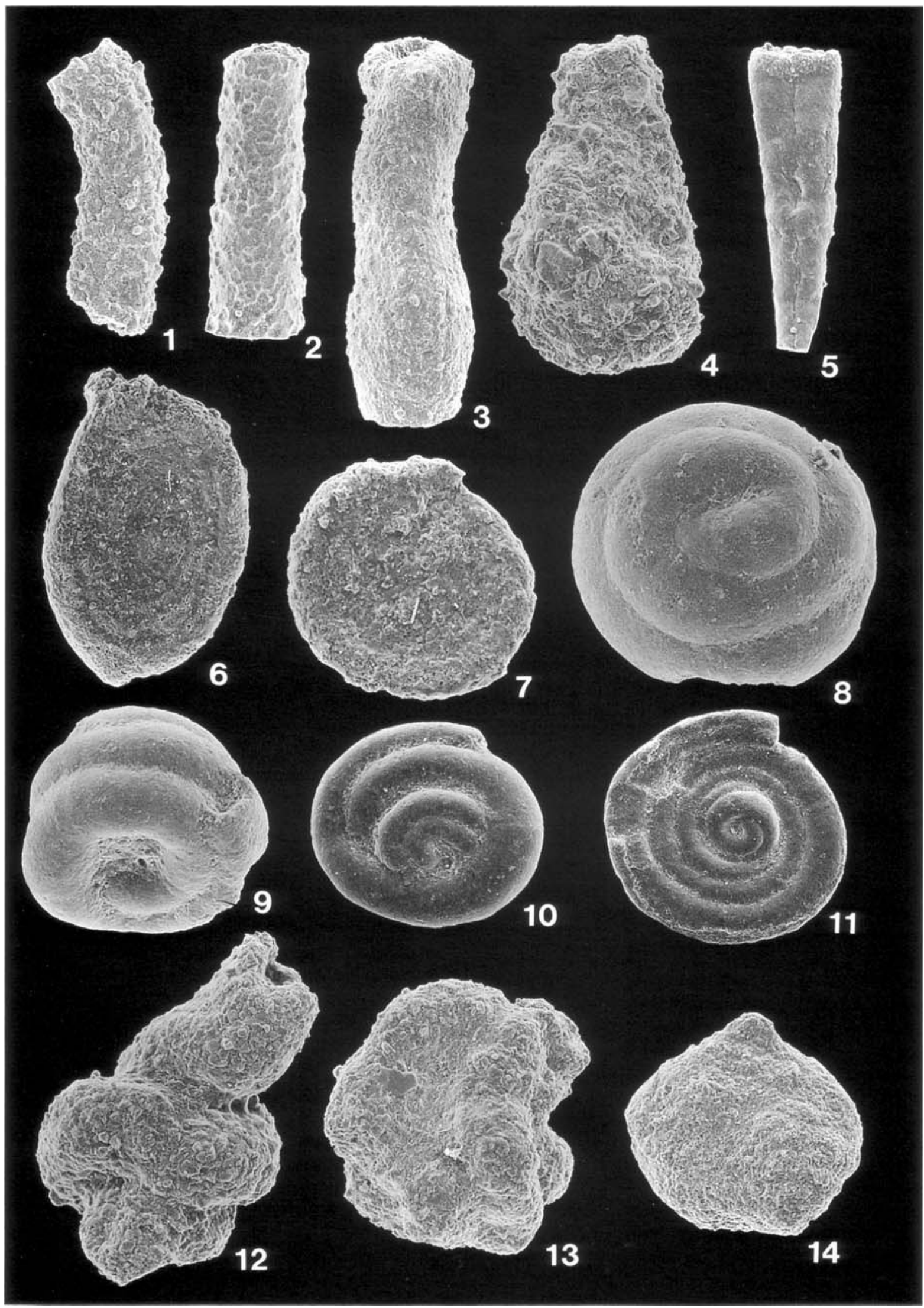

Plate 1 
Tagus abyssal plain but also the southern Iberian margin and Alboran block.

TAXONOMIC NOTES (excluding redeposited species) Specimens figured are deposited in the micropalaeontology collection of the Geologisch-Paläontologisches Institut und Museum der Christian-Albrechts Universität zu Kiel.

Ammodiscus cretaceus Reuss, 1845

1845 Operculina cretacea Reuss: 35, pl. 13, figs 64, 65 a-b. 1972 Ammodiscus cretaceus (Reuss); Hanzlikova: 34, pl. 3, fig. 9.

1974 Ammodiscus incertus (d'Orbigny); Bartenstein: 687, pl. 3, figs 14-17.

1978 Ammodiscus cretaceus (Reuss); Krasheninnikov \& Pflaumann: 569, pl. 2, fig. 7.

1992 Ammodiscus cretaceus (Reuss); Kaminski, Gradstein \& Geroch: 252, pl. 2, fig. 2.

Remarks. With relatively broad whorls in a regular planispiral coil. Whorls moderately overlap the previous one. Surface smooth, the wall is siliceous, homogenous or with very fine grains.

\section{Ammodiscus tenuissimus (Guembel, 1862)}

$$
\text { (Pl. 1, figs 6-7) }
$$

1862 Spirillina tenuissima Guembel: 214, pl. 13, fig. 2.

1967 Ammodiscus tenuissimus (Guembel); Michael: 22, pl. 1, fig. 13.

1969 Ammodiscus tenuissimus (Guembel); Grün: 312, pl. 1, fig. 13 (with synonymy).

1972 Ammodiscus tenuissimus (Guembel); Neagu: 191, pl. 1, figs 19-20.

1974 Ammodiscus tenuissimus (Guembel); Bartenstein: 687, pl. 3, figs $7-13$.

1990 Ammodiscus tenuissimus (Guembel); Geroch \& Olszewska: 529, pl. 2, figs. 6-8.

1992 Ammodiscus tenuissimus (Guembel); Kaminski, Gradstein \& Geroch: 252, pl. 2, fig. 3.

\section{Bulbobaculites sp. A}

(Pl. 3, figs 7-11)

1992 Bulbobaculites inconstans (Bartenstein \& Brand); Kaminski, Gradstein \& Geroch: 252-253, pl. 4, figs 9-10.

Remarks. Small stout forms with $1-3$ chambers in the uniserial stage. Aperture terminal on a protruding neck. This form differs from the various subspecies of Haplophragmoides inconstans Bartenstein \& Brand in its significantly smaller size, its shorter uniserial part and less elongated chambers in its uniserial part. These morphologic differences may be simply explained by environmental adaption to oligotrophic deep-sea conditions. However, since intermediate forms are not known so far, I prefer to keep the deep-sea forms in open nomenclature.
Gaudryina oblonga Zaspelova, 1948

(Pl. 4, figs 17-18)

1948 Gaudryina oblonga Zaspelova: 200, pl. 1, fig. 7. 1981 Gaudryina oblonga Zaspelova; Morgiel \& Olszewska: 18 , pl. 5, figs 2-3.

1984 Gaudryina oblonga Zaspelova; Geroch \& Nowak, pl. 2, figs 6-7; pl. 7, figs 16-17.

Remarks. Ranges in the Polish External Carpathians from the Hauterivian to the Albian.

Glomospira charoides (Jones \& Parker, 1860)

(Pl. 1, figs 8-9)

1860 Trochammina squamata Jones \& Parker, var. charoides Jones \& Parker: 304.

1928 Glomospira charoides (Jones \& Parker) var. corona Cushman \& Jarvis: 89, pl. 12, figs. 9-11.

Remarks. This species has recently been assigned to the genus Usbekistanina Suleymanov (Charnock \& Jones, 1990). For the sake of consistency $G$. charoides is kept here in Glomospira.

\section{Glomospira gordialis (Jones \& Parker, 1860)}

(Pl. 1, fig. 10)

1860 Trochammina squamata Jones \& Parker var. gordialis Jones \& Parker: 304.

Remarks. Irregularly coiled tubes, last whorl in general lying in one plane, diameter of the tube is low, characteristic is the smooth, very finely agglutinated wall.

Glomospira irregularis (Grzybowski, 1898)

(Pl. 1, figs 12-13)

1898 Ammodiscus irregularis Grzybowski: 285, pl. 11, figs 2-3.

1966 Glomospira irregularis (Grzybowski); Geroch, pl. 8, figs $11-12$.

Glomospirella gaultina (Berthelin, 1880)

(Pl. 1, fig. 11)

1880 Ammodiscus gaultinus Berthelin: 19, pl.1, fig. 3a-b.

1978 Glomospirella gaultina (Berthelin); Krasheninnikov \& Pflaumann: 568 , pl. 2, fig. 5.

Remarks. Differs from $G$. gordialis in possessing at least two planispiral coils.

\section{Haplophragmoides $\mathrm{cf}$. concavus (Chapman, 1892)}

(Pl. 2, figs 15-16)

1892 cf. Trochammina concava Chapman: 327, pl. 6, fig. $14 \mathrm{a}-\mathrm{b}$.

1960 Haplophragmoides cf. concava (Chapman); Geroch: 127, pl. 5, fig. 2.

1988 Haplophragmoides cf. concavus (Chapman); Moullade et al.: 364 , pl. 8, figs. 8-9.

\section{Explanation of Plate 2}

Figs 1-9. Pseudoreophax cisounicensis Geroch 1961, sample E30/10, 1-3: $\times 240,4-5: \times 170,6-9: \times 200$. Figs 10-11. Haplophragmoides sp.A, sample E30/10, $\times 170$. Figs 12-13. Haplophragmoides sp.B, sample E30/10, $\times 170$. Fig. 14. Trochammina sp.A, sample E30/10, $\times 200$. Figs 15-16. Haplophragmoides cf. concavus (Chapman 1892), sample E30/11, $\times 240$. 


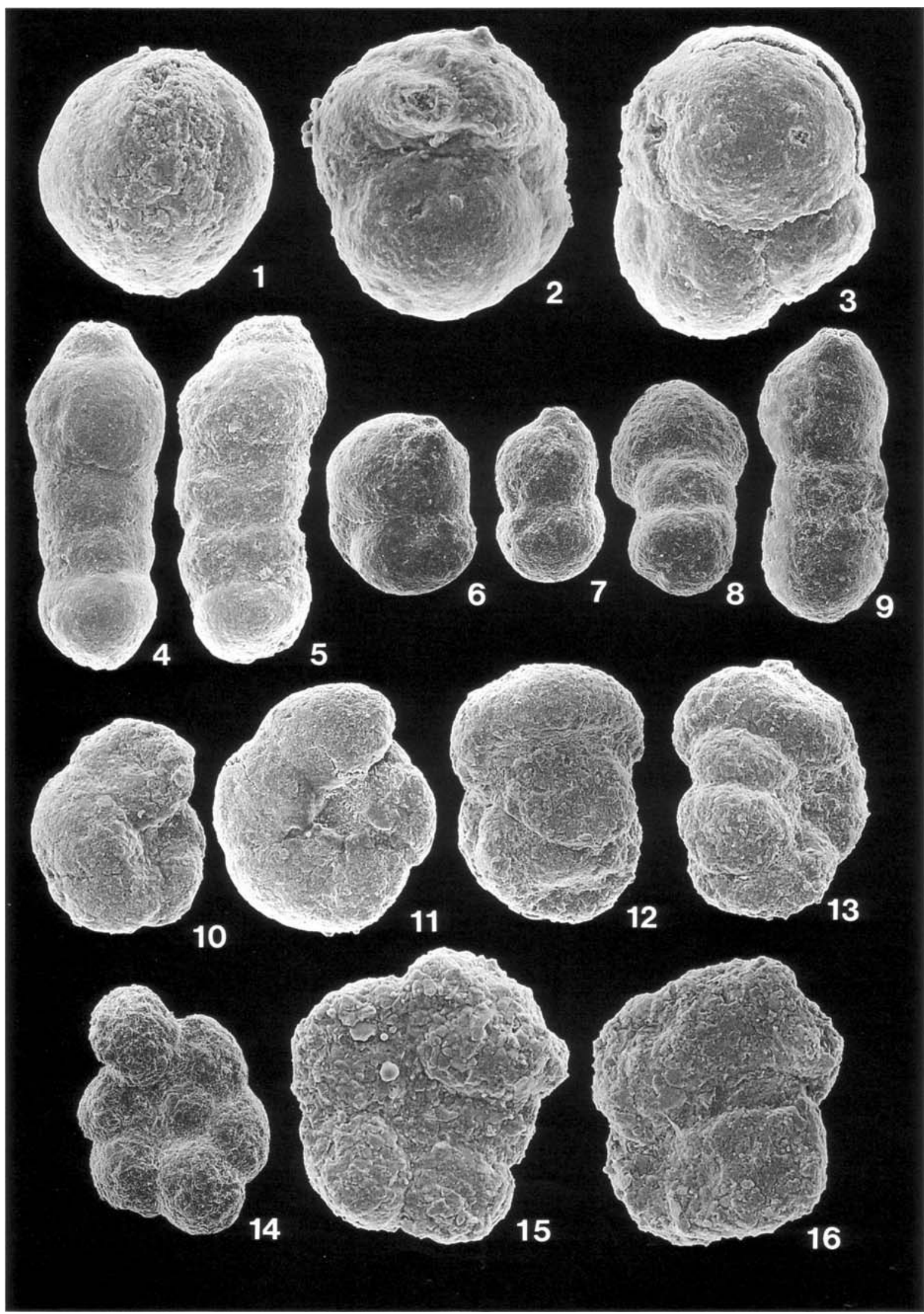

Plate 2 
1990 Haplophragmoides cf. concavus (Chapman); Kuhnt: 312 , pl. 4, fig. 13 .

Remarks. Differs from typical $H$. concavus in its smaller size and in its sometimes roughly finished wall surface.

\section{Haplophragmoides sp. A}

(Pl. 2, figs 10-11)

Remark. Test small, smooth, with four to five chambers in the last whorl and a rounded periphery.

\section{Haplophragmoides sp. B}

(Pl. 2, figs 12-13)

1992 Haplophragmoides kirki Wickenden; Kaminski, Gradstein \& Geroch: 253, pl. 4, figs 1a-b, 2.

Remarks. This form resembles Haplophragmoides kirki Wickenden, a shallow-water form from the Upper Cretaceous of Alberta, in its planispiral test with four or five globular chambers in the last whorl. Haplophragmoides sp. B is kept separate here because of its significantly smaller size, and its different stratigraphic and environmental distribution.

\section{Hippocrepina depressa Vasicek, 1947}

(Pl. 1, fig. 5)

1947 Hippocrepina depressa Vasicek: 243, pl. 1, figs 1-2.

1979 Hippocrepina depressa Vasicek; Sigal, pl. 1, fig. 5.

1980 Hippocrepina depressa Vasicek; Sliter, pl. 1, figs 2-3.

1981 Hippocrepina depressa Vasicek; Morgiel \& Olszewska: 7, pl. 1, figs 1, 2.

1982 Hippocrepina depressa Vasicek; Morgiel \& Olszewska, pl. 1, figs 1, 2.

1984 Hippocrepina depressa Vasicek; Geroch \& Nowak: 228, pl. 1, fig. 7, pl. 5, fig. 4-5.

1986 Hippocrepina depressa Vasicek; Bartenstein \& Bolli: $947-948$, pl. 1, figs $9-10$.

1989 Jaculella depressa (Vasicek); Riegraf \& Luterbacher: 1085-1986, pl. 1, figs 4-6.

Remarks. $H$. depressa is a very characteristic species of the Lower- to Mid-Cretaceous 'flysch' and pelitic series of the Polish Carpathians and the Gibraltar Arch area. Specimens of Leg 50 DSDP in the eastern North Atlantic belong to a deep-sea foraminiferal assemblage of Berriasian(?)Valanginian age with water depths of $2000 \mathrm{~m}$ and more (Sliter, 1980). It is not yet clear, whether this species can be included in the living Hippocrepina or is more related to the Palaeozoic genus Hyperamminoides Cushman \& Waters, 1928, which belongs to the Palaeozoic to Lower Cretaceous family Hyperamminoididae Loeblich \& Tappan, 1984. The type species of Hyperamminoides (Hyperamminoides elegans Cushman \& Waters, 1928 from the Upper Carboniferous of Texas) closely resembles $H$. depressa in having a very fine-grained arenaceous wall with polished surface that probably was somewhat flexible in life, as fossil specimens are generally compressed, whereas other foraminifers in the same assemblages are not compressed (Loeblich \& Tappan, 1988).

Stratigraphic range: according to Geroch \& Nowak (1984) this species ranges from Upper Hauterivian (D. hauteriviana Zone) to Upper Cenomanian (B. problematicus Zone). In the Gibraltar Arch area $H$. depressa is observed in Hauterivian to Cenomanian deep water sequences. Also recovered in DSDP-cores from the North Atlantic (e.g. Sigal (1979), Site 398 from the Hauterivian; Sliter (1980), Site 416 from the Valanginian). Characterizing deep-water assemblages.

Hyperammina gaultina Ten Dam, 1950

1950 Hyperammina gaultina Ten Dam: 5, pl. 1, fig. 2.

1974 Hyperammina gaultina Ten Dam; Bartenstein: 685, pl. 1 , figs $5-30,35,36$; pl. 2 , figs $1-4$ (with synonymy).

1990 Hyperammina gaultina Ten Dam; Geroch \& Olszewska: 529 , pl. 1, figs $1-18,25-27$; pl. 4, figs $1-15$ (with synonymy).

\section{Hyperammina cf. dilatata Grzybowski, 1896}

$$
\text { (Pl. 1, fig. 4) }
$$

1896 cf. Hyperammina dilatata Rzehak; Grzybwoski: 274-275, pl. 8, fig. 17.

1988 cf. Hyperammina dilatata Grzybowski; Kaminski et al.: 184, pl. 2, figs 1-2.

Remarks. Differs from typical Hyperammina dilatata in possessing a more coarsely agglutinated wall with a rough surface.

\section{Pseudobolivina cf. munda Krasheninnikov, 1973}

$$
\text { (Pl. 4, figs 4-6) }
$$

1973 cf. Pseudobolivina munda Krasheninnikov: 210, pl. 2, figs $10-11$.

Remarks. Differs from the typical Late Cretaceous $P$. munda in possessing a slightly twisted initial portion. Differs from $P$. variabilis Vasicek 1947 in possessing an apertural neck. Morphologically similar forms of the genus Plectinella do not possess a terminal aperture produced on a short neck.

\section{Pseudobolivina sp. A}

(Pl. 4, figs 9-11)

Remarks. After an initial regular biserial stage with a tendency to becoming uniserial with the last 3 chambers. Differs from Pseudobolivina variabilis Vasicek 1947 in its tendency to a uniserial final stage and in a twisted chamber arrangement.

Pseudoreophax cisovnicensis Geroch, 1961

(Pl. 2, figs 1-9; Pl. 3, fig. 12)

1961 Pseudoreophax cisovnicensis Geroch, p. 159, pl. 17, figs $1-5$.

\section{Explanation of Plate 3}

Figs 1-3. Trochammina quinqueloba Geroch 1959, sample E30/10, $\times 240$. Figs 4-6. Thalmannammina cf. neocomiensis Geroch 1962 , sample E30/11, $\times 240$. Figs 7-11. Bulbobaculites sp. A, sample E30/10, 7-9: $\times 240,10: \times 170,11: \times 240$. Fig. 12. Pseudoreophax cisounicensis Geroch 1961, sample E30/10, $\times 170$. Fig. 13-14. Uvigerinammina sp. 1, sample E30/10, $\times 170$. 


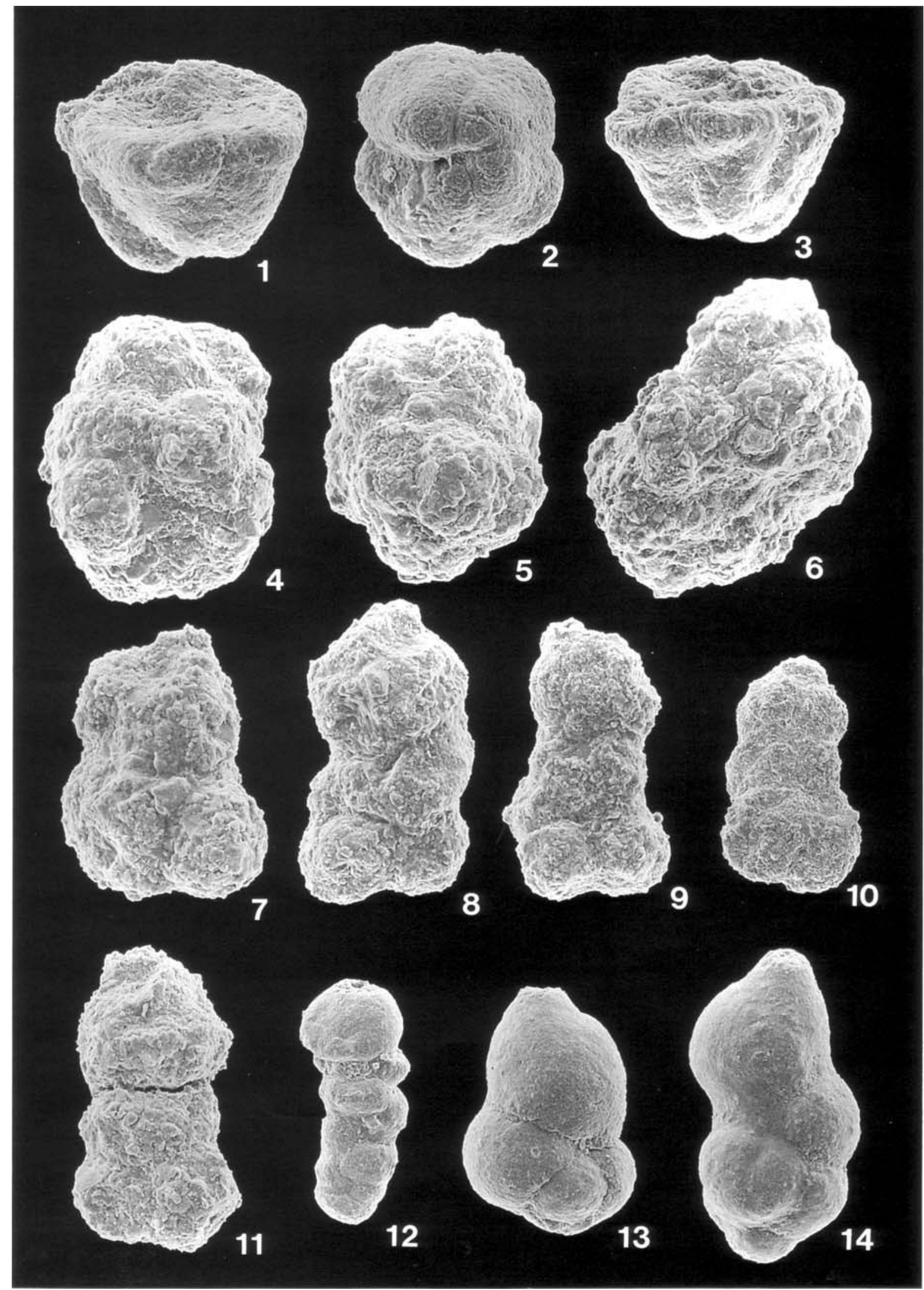

Plate 3 
1966 Pseudoreophax cisounicensis Geroch; Geroch, pl. 11, fig. 5a-c.

1980 Ammobaculites irregularis (Guembel); Sliter, pl. 2, fig. 14.

1983 Bigenerina jurassica (Haeusler); Gradstein, pl. 1, fig. 1. 1984 Pseudoreophax cisounicensis Geroch; Geroch \& Nowak, pl. 3, figs 14-18, pl. 7, figs 26-29.

1989 Pseudoreophax cisovnicensis Geroch; Riegraf \& Luterbacher: 1093, pl. 2, fig. 22.

1990 Pseudoreophax cisounicensis Geroch; Geroch \& Olszewska: 531, pl. 3, figs 1-11, 17; pl. 4, figs 16-18, 23, 24, $28,29,33,34$.

1992 Pseudoreophax cisovnicensis Geroch; Kaminski, Gradstein \& Geroch: 255, pl. 7, figs 5-6.

Remarks. Occurrences: Tithonian to Barremian of the Polish Carpathians (Geroch \& Nowak, 1984).

\section{Rhabdammina cylindrica Glaessner, 1937}

Pl. 1, fig. 2

1937 Rhabdammina cylindrica Glaessner: 354 , pl. 1 , fig. 1. 1990 Rhabdammina cylindrica Glaessner; Kaminski et al.: 364, pl. 1, figs 4a-b.

1992 Rhabdammina cylindrica Glaessner; Morlotti \& Kuhnt: 223, pl. 2, fig. 1.

Remarks. Straight tubular fragments with a circular cross-section. The available material does not allow the identification of a central chamber. It can not be excluded, however, that these fragments may be radiating tubular arms of Rhabdammina abyssorum Carpenter, 1869.

\section{Rhizammina cf. indivisa Brady, 1884}

(Pl. 1, fig. 1)

1884 Rhizammina indivisa Brady: 277, pl. 29, figs 5-7. 1981 Rhizammina indivisa Brady; Gradstein \& Berggren: 240, pl. 1, figs $1-3$.

Remarks. The assignment to the flexible, loosely agglutinated Recent species $R$. indivisa is doubtful (Charnock \& Jones, 1990). However, the species differs from Nothia excelsa (Grzybowski) in its smaller size, a thin wall composed of small quartz grains with much cement, and a generally strongly compressed outline, indicating that the individuals originally may have been flexible.

\section{Saccammina grzybowskii (Schubert, 1902)}

$$
\text { (Pl. 1, fig. 14) }
$$

1898 Reophax difflugiformis Brady; Grzybowski: 255, pl. 10, figs 11-12.

1902 Reophax grzybowskii Schubert: 20, pl. 1, fig. 13.

1912 Pelosina complanata Franke: 107, pl. 3, fig.1a-b.

1928 Pelosina complanata Franke; Franke: 10, pl. 1, fig. $6 \mathrm{a}-\mathrm{b}$.

1946 Pelosina complanata Franke; Cushman \& Renz: 13, pl. 1, fig.8.
1984 Saccammina grzybowskii (Schubert); Hemleben \& Tröster: 522, pl. 1, fig. 14.

1988 Saccammina complanata (Franke); Kaminski et al.: 183 , pl. 2, fig. 8 .

1989 Pelosina complanata Franke; Riegraf \& Luterbacher: 1085, pl. 1, fig.1.

1990 Saccammina grzybowskii (Schubert); Kuhnt: 325, pl. 2 , fig. 3 .

Remarks. Pelosina complanata Franke 1928 is regarded as a junior synonym of Saccammina grzybowskii.

Thalmannammina cf. neocomiensis Geroch, 1962

(Pl. 3, figs 4-6)

1962 cf. Thalmannammina neocomiensis Geroch: 288, pl. 1, fig. $3(5-8)$.

1981 cf. Thalmannammina neocomiensis Geroch; Morgiel \& Olszewska: 12, pl. 3, figs 12-13.

1984 cf. Thalmannammina neocomiensis Geroch; Geroch \& Nowak, pl. 3, fig. 19, pl. 6, figs 3, 4 .

Remarks. The coarse agglutination of the specimens in the Complex à Aptychus fauna does not allow a certain assignment to this species. However, the 'thalmannammine' U-shaped type of coiling can be recognized in some specimens. Thalmannammina neocomiensis ranges in the Polish External Carpathians from the Berriasian/Valanginian to Cenomanian (Morgiel \& Olszewska, 1981; Geroch \& Nowak 1984).

Trochammina quinqueloba Geroch, 1959

(Pl. 3, figs 1-3)

1959 Trochammina quinqueloba Geroch: 118, pl. 12, figs $1-3$.

1962 Trochammina quinqueloba Geroch; Neagu: 63, pl. 2 , figs 34-36.

1974 Trochammina quinqueloba Geroch; Kuznetsova, pl. 1, fig. 5 .

1980 Trochammina quinqueloba Geroch; Sliter, pl. 3, figs $16-19$.

1983 Trochammina quinqueloba Geroch; Gradstein, pl. 1, figs $10-11$.

1989 Trochammina quinqueloba Geroch; Riegraf \& Luterbacher: 1092-1093, pl. 2, figs 6-9.

1990 Trochammina quinqueloba Geroch; Geroch \& Olszewska: 531, pl. 3, figs 19-21, 23-25; pl. 4, figs 25-27, 30-32.

1992 Trochammina quinqueloba Geroch; Kaminski, Gradstein \& Geroch: 256, pl. 6, figs 3, 4a-b.

\section{Trochammina sp.A}

(Pl. 2, Fig. 14)

Remarks. Test small, low trochospiral, with up to six globular chambers in the last whorl.

\section{Explanation of Plate 4}

Figs 1-3. Trochamminoides cf. variolarius (Grzybowski 1898), sample E30/10, $\times 170$. Figs 4-6. Pseudobolivina cf. munda Krasheninnikov 1973, sample E30/10, 4: $\times 170,5-6: \times 240$. Figs 7-8. Dorothia praehauteriviana Dieni \& Massari 1966, sample E30/20 (redeposited assemblage), $\times 65$. Figs 9-11. Pseudobolivina sp. A, sample E30/10, $\times 200$. Figs 12-16. Verneuilinoides neocomiensis (Mjatliuk 1939), samples E30/10 and E30/11, $\times 170$. Figs 17-18. Gaudryina oblonga Zaspelova, 1948, sample E30/10, 17: $\times 200,18: \times 125$. 


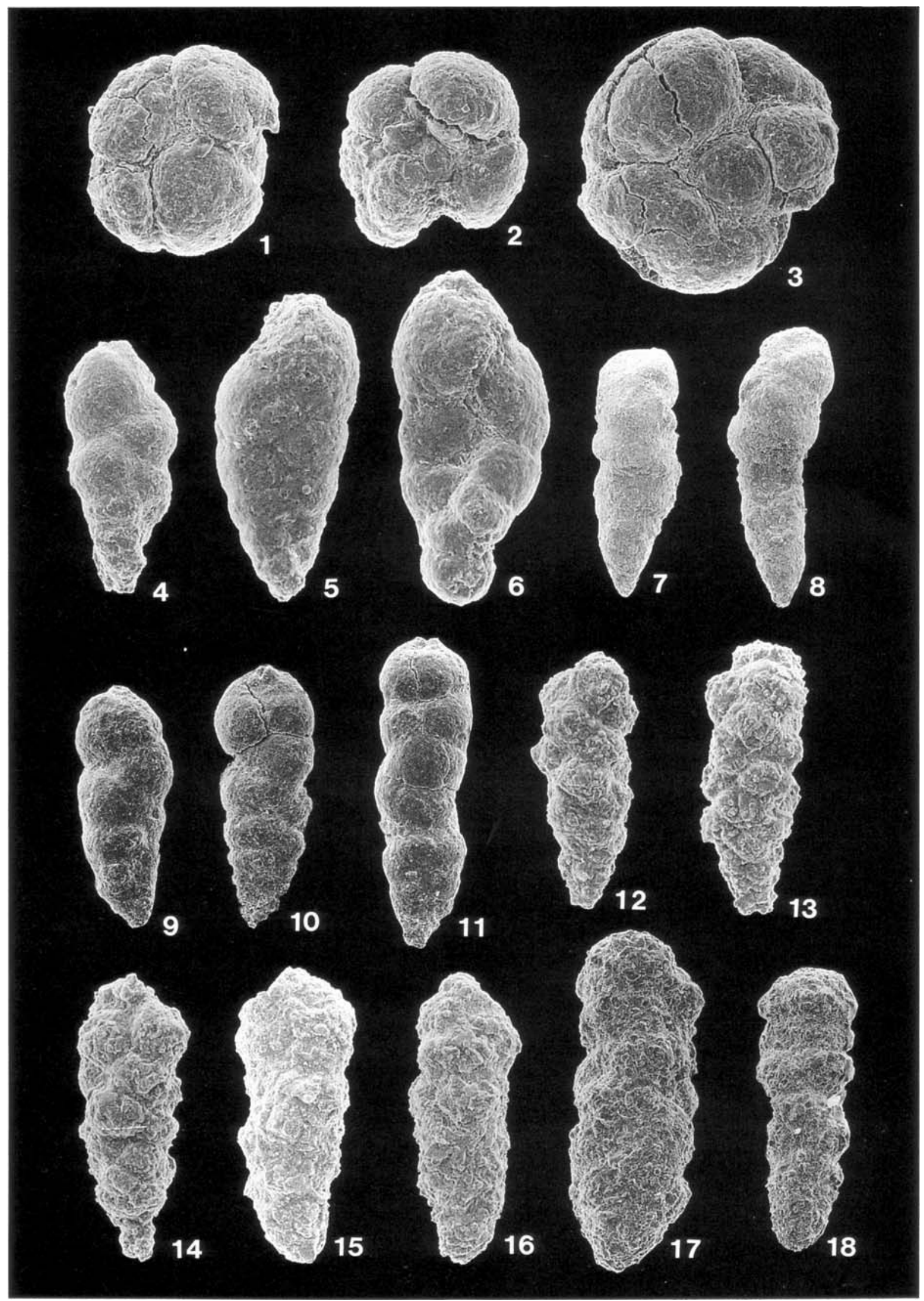

Plate 4 
Trochamminoides cf. variolarius (Grzybowski, 1898) (PI. 4, fig. 1-3)

1898 cf. Trochammina variolaria Grzybowski: 288, pl. 11, fig. 15.

1964 cf. Trochamminoides variolarius (Grybowski); Grün et al.: 267, pl. 4, figs 12,14 .

1990 cf. Trochamminoides variolarius (Grybowski); Kuhnt \& Kaminski: 487, pl. 4, figs g-h.

Remarks. The test is coiled in a somewhat irregular low trochospire. Finely agglutinated wall with a mooth surface.

Verneuilinoides neocomiensis (Mjatliuk, 1939)

(Plate 4, figs 12-16)

1939 Verneuilina neocomiensis Mjatliuk: 50, pl. 1, figs 12-13. 1962 Verneuilinoides neocomiensis (Mjatliuk); Flandrin, Moullade \& Porthault: 216, pl. 1, fig. 4; pl. 2, fig. 7.

1974 Verneuilinoides neocomiensis (Mjatliuk); Kuznetsova, pl. 1, figs $6 \mathrm{a}-\mathrm{c}$.

1984 Verneuilinoides neocomiensis (Mjatliuk); Geroch \& Nowak, pl. 2, fig. 4, pl. 7, figs 13-14.

1992 Verneuilinoides neocomiensis (Mjatliuk); Kaminski, Gradstein \& Geroch: 256, pl. 7, fig. 13.

Remarks. Triserial arrangment of chambers throughout. Reported stratigraphic range : Valanginian-Barremian in the Polish outer Carpathians (Geroch \& Nowak, 1984) and latest Tithonian to earliest Valanginian at ODP Site 765 in the Indian Ocean (Kaminski et al., 1992).

\section{Uvigerinammina sp. 1}

(Plate 3, figs 13-14)

1992 Uvigerinammina sp. Kaminski, Gradstein \& Geroch: 256, pl. 7, figs 10-11.

Remarks. Differs from Falsogaudryinella tealbyensis (Bartenstein 1956) in its agglutinated wall with diagenetically silicified organic cement, its more rounded aperture and in its less elongated test morphology. The genera Falsogaudryinella and Uvigerinammina are separated mainly on the basis of cement type, with Falsogaudryinella possessing calcareous cement and Uvigerinammina organic cement (Kaminski et al., in press).

\section{ACKNOWLEDGEMENTS}

The study of the palaeoecology and biogeography of deep-water benthic foraminifera in various basins of the Western Mediterranean is part of the ALKAPECA-project at the University of Tübingen which is supported by the Deutsche Forschungsgemeinschaft. I am grateful to all members of the working group, especially Thomas Pletsch, Klaus Reicherter and Jost Wiedmann for their support and stimulating discussion. I also want to thank Jürgen Thurow (University of Bochum) for joint field-work in the 'Corridor de Boyar' and for providing additional sample material. Stanislaw Geroch (Jagiellonian University, Krakow) and Michael A. Kaminski (University College London) enabled taxonomic comparison with material from the Cieszyn Limestones in the Polish Carpathians and from the Indian Ocean. Michael A. Kaminski and Michel Moullade (University of Nice) reviewed an earlier draft of this paper and provided useful comments on the taxonomy of several species.

\section{Manuscript received June 1993 \\ Manuscript accepted April 1994}

\section{References}

Azéma, J., Foucault, A., Fourcade, E., Garcia-Hernandez, M., Gonzalez-Donoso, J. M., Linares, A., Linares, D., LópezGárrido, A. C., Rivas, P. \& Vera, J. A. 1979. Las microfacies del Jurásico y Cretácico de las Zonas Externas de las Cordilleras Béticas. Ser. Publ. Univ. Granada, 1-83.

Bartenstein, H. 1956. Zur Mikrofauna des englischen Hauterive. Senckenbergiana Lethaea, 37: 509-533.

Bartenstein, H. 1974. Upper Jurassic-Lower Cretaceous primitive arenaceous foraminifera from DSDP Sites 259 and 261, Eastern Indian Ocean. In Veevers, J. J., Heirtzler, J. R. et al., Initial Reports of the Deep Sea Drilling Project, 27: Washington (U.S. Govt. Printing Office), 683-695.

Bartenstein, H. \& Bolli, H. M. 1986. The foraminifera in the Lower Cretaceous of Trinidad, W.I. Part 5: Maridale Formation. Upper Part: Hedbergella rohri zone. Eclogae geologicae Helvetiae, 79: 945-999.

Berthelin, G. 1880. Memoire sur les foraminiferes fossiles de l'etage Albien de Montcley (Doubs). Memoires de la Societe Geologique de France, série 3, 1: 1-84.

Blumenthal, M. M. 1927. Zum Bauplan betischer und penibetischer Decken im Norden der Provinz Malaga. Geologische Rundschau, 17: $37-45$.

Blumenthal, M. M. 1935a. Antibetische Faltungen im Gibraltarbogen. Geologische Rundschau, 26: 424-429.

Blumenthal, M. M. 1935b. Allure de la tectonique et définition du 'double pli Gaditan' (Andalousie). Bulletin de la Société Géologique de France, 5: 659-686.

Blumenthal, M. M. 1936. Le matériel stratigraphique du 'double pli Gaditan' (Andalousie). Bulletin de la Société Géologique de France, 6: 511-537.

Bourgois, J. 1978. La transversale de Ronda (Cordillères bétiques, Espagne)-données géologiques pour un modèle d'évolution de l'Arc de Gibraltar. Anuales scientifiques de l'Universite Franche-Comte, Besaçon, 3me série, 30: 1-445.

Brady, H. B., 1884. Report on the foraminifera dredged by HMS Challenger, during the years 1873-1876. Report of Scientific Results Exploration Voyage HMS Challenger, Zoology, 9: 1-814.

Chapman, F. 1892. The Foraminifera of the Gault of Folkstone, Part II. Journal of the Royal Microscopical Society (1892), 318-330.

Charnock, M. A. \& Jones, R. W. 1990. Agglutinated foraminifera from the Paleogene of the North Sea. In Hemleben, C., Kaminski, M. A., Kuhnt, W. \& Scott, D. B. (Eds), Paleoecology, Biostratigraphy, Paleoceanography and Taxonomy of Agglutinated Foraminifera, NATO-ASI Series, Vol. C327, 139-244.

Cushman, J. A. \& Jarvis, P. W. 1928. Cretaceous foraminifera from Trinidad. Contributions from the Cushman Laboratory for Foraminiferal Research, 4: 85-103.

Cushman, J. A. \& Renz, H. H. 1946. The foraminiferal fauna of the Lizard Springs Formation of Trinidad, British West Indies. Cushman Laboratory for Foraminiferal Research Special Publiations, 18: 1-48.

Cushman, J. A. \& Waters, J. A. 1928. Hyperamminoides, a new name for Hyperamminella Cushman \& Waters. Contributions from the Cushman Laboratory for Foraminiferal Research, 4: 112.

Dercourt, J., Zonenshain L. P., Ricou, L. E., Kazmin, V. G., Le Pichon, X., Knipper, A. L., Grandjacquet, C., Sborshchikov, I. M., Boulin, J., Sorokhtin, O., Geyssant, J., Lepvrier, C., Biju-Duval, B., Sibuet, J.-C., Savostin, L.A., Westphal, M. \& Lauer, J.-P. 1985. Présentation de 9 cartes paléogéographiques au 1/20.000.000 s'étendant de l'Atlantique au Pamir la période du Lias à 1 'Actuel. Bulletin de la Société Géologique de France, 5: $637-652$. 
Didon, J., Durand-Delga, M. \& Kornprobst, J. 1973. Homologies géologiques entre les deux rives du détroit de Gibraltar. Bulletin de la Société géologique de France, 15: 77-105.

Dubois, M. 1971. Etude géologique des environs d'Ubrique (Province de Cadix-Espagne). Thèse 3eme cycle, Université de Besançon.

Durand Delga, M. 1980. Considérations sur les flysch du Crétacé inférieur dans les chaînes alpines d'Europe. Bulletin de la Société Géologique de France, 22: 1-30.

Fallot, P. 1930. Etat de nos connaissances sur la structure des chaînes bétique et subbétique. Livre jubilaire S. G. F., 279-305.

Fallot, P. 1948. Les Cordillères bétiques. Estudios geológicos, 4: $83-172$.

Flandrin. J., Moullade, M. \& Porthault, B. 1962. Microfossiles caracteristiques du Cretace inferieur Vocontien. Revue de Micropaléontologie, 4: 211-228.

Franke, A. 1912. Die Foraminiferen des Unter-Eocntones der Ziegelei Schwarzenbeck. Jahrbuch der Preussisdien Geolgischen Laudesanstalt, 32: 106-111.

Franke, A. 1928. Die Foraminiferen der Oberen Kreide Nord- und Mitteldeutschlands. Jahrbuch der Preussisdien Geolgischen Laudesanstalt, 111: 1-207.

Geroch, S. 1959. Stratigraphic significance of arenaceous foraminifera in the Carpathian Flysch. Palaeontologische Zeitschrift, 33: $113-122$.

Geroch, S. 1960. Microfaunal assemblages from the Cretaceous and Paleogene Silesian unit in the Beskid Slaski Mts. (Silesian Carpathians). Poland Instytut Geologiczny, Biulytin, 153: 7-138.

Geroch, S. 1961. Pseudoreophax a new genus of foraminifer from the Neocomian in the Flysch Carpathians. Annales de la Société Géologique de Pologne, 31: 159-165.

Geroch, S. 1962. Thalmannammina and Plectorecunoides (Foraninifera) in the Lower Cretaceous of the Flysch Carpathians. Annales de la Société Géologique de Pologne, 32: 281-300.

Geroch, S. 1966. Lower Cretaceous small foraminifera of the Silesian Series, Polish Carpathians. Annales de la Société Géologique de Pologne, 36: 413-480.

Geroch S. \& Nowak, W. 1984. Proposal of zonation for the late Tithonian-late Eocenc, based upon arenaceous foraminifera from the outer Carpathians, Poland. In Oertli, H. J. (Ed.), Benthos '83, 2nd International Symposium on Benthic Foraminifers (Pau, April 1983), 225-239.

Geroch, S. \& Olszewska, B. 1990. The oldest assemblages of agglutinated foraminifers of the Polish Carpathians. In Hemlcben, C., Kaminski, M. A., Kuhnt, W. \& Scott, D. B. (Eds), Paleoecology, Biostratigraphy, Paleoceanography and Taxonomy of Agglutinated Foraminifera, NATO-ASI Series, Vol. C327, $525-538$.

Glaessner, M. F. 1937. Studien über Foraminiferen as der Kreide und dem Tertiär des Kaukasus, 1. Die Foraminiferen der ältesten Tertiärschichten des Nordwest-Kaukasus. Problemy Paleont., 2-3: $349-408$.

Gooday. A. J. 1990. Recent deep-sea agglutinated foraminifera: a brief review. In Hemleben, C., Kaminski, M. A., Kuhnt, W. \& Scott. D. B. (Eds), Paleoecology, Biostratigraphy, Paleoceanography and Taxonomy of Agglutinated Foraminifera, NATO-ASI Scries, Vol. C327, 271-304.

Gradstein, F. M. 1978. Biostratigraphy of Lower Cretaceous Blake Nose and Blake Bahama-Basin foraminifers DSDP Leg 44, Western North Atlantic Ocearı. Initial Reports of the Deep Sea Drilling Project, Washington (U.S. Govt. Printing Office), 44: 663-701.

Gradstcin, F. M. 1983. Paleoecology and stratigraphy of Jurassic abyssal foraminifera in the Blake Bahama Basin, Deep Sea Drilling Project Site 534. In Sheridan, R. E. \& Gradstein, F. M. (Eds) Initial Reports of the Deep Sea Drilling Projects, 76: $537-559$.

Gradstein, F. M. \& Berggren, W. A. 1981. Flysch-type agglutinated foraminifera and the Maestrichtian to Paleocene history of the Labrador and North Seas. Marine Micropalaeontology, 6: $211-268$.
Grün, W. 1969. Flysch microfauna of the Hagenbach-Valley (Northern Vienna Woods), Austria. Rocznik Polskiego Towarzystwa Geologicnego, 39: 305-334.

Grün, W., Lauer, G., Niedermayer, G. \& Schnabel, W. 1964. Die Kreide-Tertiär-Grenze im Wienerwaldflysch bei Hochstra(Niederösterreich). Verh. Geol. B.A. Wien, 1964/2: 226-274.

Grzybowski, J. 1896. Otwornice czerwonych ilow z Wadowic. Rozprawy Wydzialu Matemat. Przyrod. Akad. Umiejetnosci w Krakowie, 30: 261-308.

Grzybowski, J. 1898. Otwornice pokladow naftonosnych okolicy Krosna. Rocz. Akad. Umiejet., Wydz. matem.-przyrod., 33: 257-305.

Gümbel, C. W. 1862. Die Streitberger Schwammlager und ihre Foraminifereneinschlüsse. $J h$. Ver. vaterl. Naturkde. Württ, 18: 192-238.

Hanzlikova, E. 1972. Carpathian Upper Cretaceous Foraminifera of Moravia (Turonian-Maestrichtian). Ustred Ustav. Geol. Rozpravy, 39: 5-159.

Hemleben, C. \& Tröster, J. 1984. Campanian-Maestrichtian deep-water foraminifers from Hole 543A, Deep Sea Drilling Project. In Bij-Duval, B. \& Moore, J. C. (Eds) Initial Reports of the Deep Sea Drilling Project 78A: 509-532.

Hoeppener, R., Hoppe, P., Dürr, S. \& Mollat, H. 1964a. Ein Querschnitt durch die Betischen Kordilleren bei Ronda (SW-Spanien). Geologie en Mijnbouw, 43: 282-298.

Hoeppener, R., Hoppe, P., Mollat, H., Muchow, S., Dürr, S. \& Kockel, F. 1964b. Uber den westlichen Abschnitt der Betischen Kordilleren und seine Beziehungen zum Gesamtorogen. Geologische Rundschau, 53: 269-296.

Hoppe, P. 1968. Stratigraphie und Tektonik der Berge um Grazalema (SW-Spanien). Geologisches Jahrbuch, 86: 267-338.

Jansa, L. F., Enos, P.. Tucholke, B. E., Gradstein, F. M. \& Sheridan, R. E. 1979. Mesozoic-Cenozoic sedimentary formations of the North American Basin, westerm North Atlantic. In Talwani, M., Hay, W. \& Ryan, W. B. F. (Eds), Deep Drilling Results in the Atlantic Ocean: Continental Margins and Paleo-Environment. American Geophysical Union, 3: 1-57.

Jones, T. R. \& Parker, W. K. 1860). On the rhizopodal fauna of the Mediterranean compared with that of the Italian and some Tertiary deposits. Journal of Geological Society, London, 16: 292-307.

Kaminski, M. A., Gradstein, F. M., Berggren, W. A., Geroch, S. \& Beckmann, J. P. 1988. Agglutinated foraminiferal assemblages from Trinidad: taxonomy, stratigraphy and palaeobathymetry. In Gradstein, F. M. \& Rögl, F. (Eds) Second International Workshop on Agglutinated Foraminifera, Vienna 1986, Proceedings, Abh. geol. Bundesanst. (Wien), 41: 155-228.

Kaminski, M. A., Gradstein, F. M., \& Geroch, S. 1992. Uppermost Jurassic to Lower Cretaceous deep-water benthic foraminiferal assemblages from Site 765 on the Argo Abyssal Plain. In Gradstein, F. M., Ludden, J. N. et al., Proc. ODP, Sci Results, 123: 239-269.

Kaminski, M. A., Gradstein, F. M., Goll, R. M. \& Greig, D. 1990. Biostratigraphy and Paleoecology of deep-water aggutinated foraminifera at ODP Site 643, Norwegian-Greenland Sea. In Hemleben, C., Kaminski, M. A., Kuhnt, W. \& Scott, D. B. (Eds) Paleoecology, Biostratigraphy, Paleoceanography and Taxonomy of Agglutinated Foraminifera, NATO ASI Series, Series C: Mathematical and Physical Sciences, 327: 345-386.

Kaminski, M. A., Ncagu, T. \& Platon, E., in press. A revision of Lower Cretaceous Falsogaudryinella from the North Sea and Romania and its relationship to the genus Uvigerinammina (Sarcodina, Foraminiferida). In Proceedings of the Fourth International Workshop on Agglutinated Foraminifera. Grzykowski Foundation Special Publication, 3, Krakow, Poland.

Krasheninnikov, V. A. 1973. Cretaceous benthonic foraminifera, Leg 20, Deep Sea Drilling Project. In Heezen, B. C., MacGregor, I. D., et al., Initial reports of the DSDP, 20: 205-219. ,

Krasheninnikov, V. A. \& Pflaumann, U. 1978. Cretaceous agglutinated foraminifera of the Atlantic Ocean off west Africa (Leg 41, Deep Sea Drilling Project). In Lancelot, Y., Seibold, E. 
et al., Initial Reports of the Deep Sea Drilling Project, 41: $565-580$

Kuhnt, W. 1990. Agglutinated foraminifera of Western Mediterrancan Upper Cretaceous pelagic limestones (Umbrian Apennines, Italy, and Betic Cordillera, Spain). Micropalaeontology, 36: 297-330.

Kuhnt, W. \& Kaminski, M. A. 1990. Paleoecology of Late Cretaceous to Paleocene deep-water agglutinated foraminifera from the North Atlantic and western Tethys. In Hemleben, C., Kaminski, M. A., Kuhnt, W. \& Scott, D. B. (Eds) Paleoecology, Biostratigraphy, Paleoceanography and Taxonomy of Agglutinated Foraminifera, NATO ASI Series, Series C: Mathematical and Physical Sciences, 327: 433--505.

Kuhnt, W., Kaminski, M. A. \& Moullade, M. 1989. Late Cretaceous deep-water agglutinated foraminiferal assemblages from the North Atlantic and its marginal seas. Geologische Rundschau, 78: $1121-1140$.

Kuznetsova, K. I. \& Seibold, I. 1977. Foraminifers from the Upper Jurassic and Lower Cretaccous of the castern Atlantic (DSDP Leg 41, Sites 367 and 370). In Lancelot, Y., Seibold, E. et al., Initial Reports of the Deep Sea Drilling Project, 41: 515-537.

Kuznetsova, K. I. 1974. Distribution of benthonic foraminifera in Upper Jurassic and Lower Cretaceous deposits at Site 261, DSDP Leg 27, in the eastern Indian Ocean. In Veevers, J. J., Heirtzler, J. R., et al., Initial Reports of the Deep Sea Drilling Project, 27: 673-681.

Leblanc, D. \& Olivier, P. 1984. Role of strike-slip faults in the Betic-Rifian orogeny. Tectonophysics, 101: 345-355.

Loeblich, A. R. \& Tappan, H. 1984. Suprageneric classification of the Foraminiferida (Protozoa). Micropalaeontology, 30: 1-70.

Loeblich, A. R. \& Tappan, H. 1988. Foraminiferal Genera and Their Classification. Van Nostrand Reinhold Company, Inc. New York.

Luterbacher, H. 1972. Foraminifera from the Lower Cretaceous and Upper Cretaceous of the northwestern Atlantic. In Hollister, C. D., Ewing, J. I., et al., Initial Reports of the Deep Sea Drilling Project, 13: 561-593.

Malod J. A. 1989. Iberian kinematics during the Cretaceouspalacogeographic consequences. In Wiedmann, J. (Ed.), Cretaceous of the Western Tethys. Proceedings 3rd International Cretaceous Symposium, Tübingen 1987. E. Schweizerbartsche Verlagsbuchhandlung, Stuttgart, 3-16.

Mauffret, A., Mougenot, D., Miles, P. R., Malod, J. A., 1989. Cenozoic deformation and Mezozoic abandoned spreading center in the Tagus Abyssal Plain (west of Portugal): results of a multichannel seismic survey. Canadian Joumal of Earth Sciences, 26: $1101-1123$.

Maync, W. 1973. Lower Cretaccous foraminiferal fauna from Gorringe Bank, castern North Atlantic. In Hollister, C.D., Ewing, J. I., et al., Initial Reports of the Deep Sea Drilling Project, 13: $1075-1111$.

Michacl, E. 1967. Dic Mikrofauna der nordwestdeutschen Barreme. Teil I-Die Foraminiferen des NW-deutschen Barreme. Palaeontographica Supplements, 12: 1-176.

Mjatliuk, E. V. 1939. Foraminiferen aus oberjurassischen und unterkretazischen Sedimenten zwischen Povolschi und Obschtschej Syrt [In Russian]. Trudy Vsesoyuznogo Neftyana Nauchnoissledovatel'skogo Geologorazvedochnogo Instituta, (VNIGRI), ser. A, 120: 1-66.

Morgicl, J. \& Olszewska, B. 1981. Biostratigraphy of the Polish
External Carpathians based on agglutinated foraminifera. Micropalaeontology, 27: 1-30.

Morgicl, J. \& Olszewska, B. 1982. Uniformity of the Tethyan faunas from Cretaceous and Paleogene as shown by foraminifera from Morocco and Polish Flysch Carpathians. Cahiers de Micropaléontologie, 3: 45-53.

Morlotti, E. \& Kuhnt, W. 1992. Agglutinated deep-water foraminifera of the Eocene Monte Piano Formation (Northern Apennines, Italy). Journal of Foraminiferal Research, 22: 214-228.

Moullade, M., Kuhnt, W. \& Thurow, J. 1988. Agglutinated benthic foraminifers from Upper Cretaceous variegated clays of the North Atlantic Ocean (DSDP Leg 93 and ODP Leg 103). In Boillot, G., Winterer, E. L. et al. (Eds) Proceedings of the Ocean Drilling Program, Scientific Results, 103: 349-377.

Neagu, T. 1962. Studiul foraminiferelor aglutinante din argilele Cretacic superioare de pe Valea Sadovei (CimpulungMoldovenesc) si bazinul superior al vaii Buzaului. Stud. Cerc. Geol. Geophys. Geogr., Ser. Geol., 7: 45-81.

Neagu, T. 1972. The Eo-Cretaceous foraminiferal fauna from the area between the Ialomitza and Prahora Valleys (Eastern Carpathians). Revista Española de Micropalaeontologia, 4: $181-224$.

Olivier, P. 1984. Evolution de la limite entre Zones internes et Zones externes dans l'Arc de Gibraltar (Maroc-Espagne). Thèse, Université Toulouse, 1-229.

Reuss, A. E., 1845. Die Versteinerungen der böhmischen Kreideformation. Schweizerbartïsche Verlagsbuchhandlung, Stuttgart, 1-145.

Riegraf, W. \& Luterbacher, H. 1989. Benthonische Foraminiferen aus der Unterkreide des 'Deep Sea Drilling Project' (Leg 1-79). Geologische Rundschau, 78: 1063-1120.

Schubert, R. J. 1902. Neue und interessante Foraminiferen aus dem südtiroler Alttertiär. Beiträge zur Palaeontologie und Geologie Osterreich-Ungarns und des Orients, 14: 9-26.

Sigal, J. 1979. Chronostratigraphy and ecostratigraphy of the Cretaceous formations recovered on DSDP Leg 47B, Site 398. In Sibuet, J. C., Ryan, W. B. F. et al. Initial Reports of the Deep Sea Drilling Project, 47/2: 287-326.

Sliter, W. V. 1980. Mesozoic foraminifers and deep-sea benthic environments from Deep Sea Drilling Project Sites 415 and 416, Eastern North Atlantic. In Lancelot, Y., Winterer, E. L., et al., Initial Reports of the Deep Sea Drilling Project, 50: 353-428.

Ten Dam, A. 1950. Les foraminiferes de l'Albien des Pays-Bas. Mémoires de la Société Géologique de France, nouvelle série, 29: $1-66$.

Thurow, J. 1987. Die kretazischen Turbiditserien im Gibraltarbogen: Bindeglied zwischen atlantischer und tethyaler Entwicklung. Thesis, Universität Tübingen.

Tucholke, B. E. \& Vogt, P. R. 1979. Western North Atlantic: Sedimentary evolution and aspects of tectonic history. In Tucholke, B. E. \& Vogt, P.R. et al., Initial Reports of the Deep Sea Drilling Project, 43: 791-825.

Vasicek, M. 1947. Remarks on the Microbiostratigraphy of the Magura Flysch in Moravia. Vestnik Stat. Geol. Ust. Rep. Cesk, 22: 235-256.

Zaspelova, V. S. 1948. Foraminifera from the Upper Jurassic and Cretaceous of the West Siberian lowland (in Russian). Trudy Neft. Nauchno-Issled. Geol.-Razved. Inst (VNIGRI), nov, ser, 31: 200. 